\title{
Description of Cathorops manglarensis, a new species from the Colombian Pacific, with redescription of Cathorops multiradiatus (Siluriformes; Ariidae)
}

\author{
ALEXANDRE P. MARCENIUK \\ Museu de Zoologia da Universidade de São Paulo, Caixa Postal 42494, CEP 04218-970, São Paulo, SP, Brazil. \\ E-mail: a_marceniuk@hotmail.com
}

\begin{abstract}
Since it was described, Cathorops multiradiatus has been differentiated from congeners through the large number of anal-fin rays (25-27). In this study, $C$. multiradiatus is redescribed and a new sympatric species with similar number of anal-fin rays is described and intersexual differences of both species evaluated. Cathorops manglarensis differs from $C$. multiradiatus by possessing few gill rakers on the first arch (13-16 vs. 16-19), a longer maxillary barbel (28.4-38.2 vs. 22.9-27.7\% SL), longer pectoral-fin spine (18.5-22.5 vs. 16.9-18.7\% SL), posterior margin of pectoral-fin spine with short and inconspicuous serrations ( $v s$. posterior margin of pectoral-fin spine with long and conspicuous serrations), dorsal-fin spine shorter than pectoral-fin spine ( $v s$. dorsal-fin spine longer than pectoral-fin spine), and large accessory tooth plates with large and numerous molariform teeth ( $v s$. small accessory tooth plates with small and few molariform teeth). The nominal species Tachysurus emmelane and Tachysurus equatorialis are considered junior synonyms of $C$. multiradiatus and a key to species of Cathorops from the Pacific coast of Central and South America is provided.
\end{abstract}

Key words: Cathorops manglarensis, C. multiradiatus, Colombia Pacific, new species, redescription

\section{Introduction}

The genus Cathorops Jordan \& Gilbert, 1882 includes species of small size, reaching a maximum length 360 mm TL, that occur mainly in estuarine and freshwater habitats from southern Mexico to Central and South America (Kailola \& Bussing, 1995; Marceniuk \& Ferraris, 2003). The species assigned to Cathorops can be easily distinguished from the species belonging to the remaining genera of Ariidae by the absence of vomerine tooth plates (with the exception of $C$. dasycephalus), presence of one pair of oval-shaped accessory tooth plates, molariform teeth on accessory plates, adipose-fin remarkably short, and lateral line not bifurcated on caudal region. Cathorops constitutes a natural group, with its monophyletic condition well defined (Marceniuk, 1997; Betancur-R., 2003; Marceniuk, 2003; Betancur-R. et al., 2004). Recently, Marceniuk \& Menezes (2007) presented a revision for the genera of the family Ariidae, redefining Cathorops through six exclusive and eleven non-exclusive anatomical characters, whereas Betancur-R. et al. (in press) supported its monophyly by ten morphological and two amino acid synapomorphies. The genus Cathorops comprises 13 species (Marceniuk \& Ferraris, 2003; Betancur-R. et al., in press), of which seven occur exclusively in the Pacific portion of America: Cathorops dasycephalus (Günther, 1864), C. fuerthii (Steindachner, 1877), C. hypophthalmus (Steindachner, 1877), C. multiradiatus (Günther, 1864), C. steindachneri (Gilbert \& Starks, 1904), C. taylori (Hildebrand, 1925), and C. tuyra (Meek \& Hildebrand, 1923).

The great similarity in external morphology and coloration, and lack of knowledge of ontogenetic and intersexual differences, often hinders correct identification of Cathorops species (Marceniuk, 1997; Marceniuk, in press). Since its description, Cathorops multiradiatus (Günther, 1864) has been recognized and differ- 
entiated from its congeners by the large number of anal-fin rays (25-27), a characteristic considered to be exclusive until the present (Eigenmann \& Eigenmann, 1890; Jordan \& Evermann, 1896; Regan, 1906; Meek \& Hildebrand, 1923; Hildebrand, 1946; Kailola \& Bussing, 1995). The diversity of the genus and taxonomic status of nominal species from western America were recently examined by Allen \& Robertson (1994), Bussing \& López (1994), Kailola \& Bussing (1995), Chirichigno \& Vélez (1998), Castro-Aguirre et al. (1999), Marceniuk \& Ferraris (2003) and Nelson et al. (2004).

In the present work, $C$. manglarensis, a new species with a similar number of anal-fin rays to Cathorops multiradiatus, is described. C. multiradiatus is redescribed and intersexual differences of both species evaluated.

\section{Material and methods}

Measurements were taken according to Marceniuk (in press). Gill rakers counts were taken on epibranchial and ceratobranquial (upper limb and lower limb). Bivariate scatterplots were used in the analyses of morphometric data and frequency distribution was used in the analysis of the meristic data. In the diagnosis, sexual dimorphism sections, identification key and data tables, all measurements are given as percentages of standard length (SL). The meristic values for the type specimens are indicated in brackets in the descriptions. Sex of specimens was determined by examination of the gonadal morphology under magnification. Variables in which differences were found between males and females are discussed under the sexual dimorphism section for each species.

The institutional abbreviations are as follows: FMNH - Field Museum of Natural History, Chicago, USA and USNM - National Museum of Natural History, Smithsonian Institution, Washington, D.C., USA.

Comparative material examined: Cathorops dasycephalus (Günther, 1864): FMNH 19143 (5, 216.0242.0 mm TL) Panama, Panama Bay, Balboa; USNM 286481 (7, 162.0-233.0 mm TL) Colombia, off Cape Manglares, south of Tumaco. Cathorops fuerthii (Steindachner, 1877): USNM 79398 (12, 185.0-242.0 mm SL) Panama, Panama Bay, Balboa, channel zone. Cathorops hypophthalmus (Steindachner, 1877): USNM 293275 (2, 168.0-185.0 mm SL) Panama, Darien province, río Pirre ca 1/2 km above El Real, río Tuyra drainage. Cathorops tuyra (Meek \& Hildebrand, 1923): USNM 286397 (1, 123.0 mm SL) Panama, río Pirre, 3-5 miles above El Real; USNM 286466 (9, 138.0-225.0 mm SL) Panama, río Pirre, 3-5 miles above El Real; USNM 286462 (1, 146.0 mm SL) Panama, río Uruseca, 2 miles above El Real; USNM 292824 (5, 149-165 mm SL) Panama, río Uruseca, 5 miles above El Real.

\section{Cathorops manglarensis, new species}

(Figs. 1 and 2)

Diagnosis. Cathorops manglarensis is distinguished from all congeners through the following combination of characters: 13-16 gill rakers on first arch; 24-27 anal fin rays; dorsal fin spine shorter than pectoral fin spine; posterior margin of pectoral fin spine with shorter serrations.

This species can be further distinguished from each of the other species from the Pacific coast of Central and South America by additional characters. Cathorops manglarensis is distinguished from C. dasycephalus in lacking vomerine tooth plates (vs. vomerine tooth plates present) and an osseous bridge formed by the lateral ethmoid and frontal without granulation (vs. granulated along its entire extension). It differs from C. fuerthii by having a median groove of neurocranium deep and large, with lateral margins regular and progressively narrower posteriorly ( $v s$. median groove narrow and shallow, with irregular margins along its entire extension), anterior nostrils closer to each other (3.6-4.8 vs. 4.9-6.0\% SL), longer external mental bar- 
bel (19.7-24.4 vs. 15.9-19.7\% SL), longer internal mental barbel (12.5-17.9 vs. 10.3-12.9\% SL), and longer anal fin base (21.0-24.5 vs. 17.8-19.4\% SL). It differs from C. hypophthalmus in possessing a shorter distance between anterior nostrils (3.6-4.8 vs. 6.9-7.1\% SL) and between posterior nostrils (5.2-7.1 vs. 8.28.5\% SL), larger orbital diameter (3.7-4.8 vs. 3.0-3.5\% SL), narrower mouth (8.8-10.5 vs. 13.1-13.2\% SL) and with shorter external mental barbel (19.7-24.4 vs. 34.5-38.1\% SL), internal mental barbel (12.5-17.9 vs. 26.1-31.2\% SL), and dorsal fin spine (16.9-19.2 vs. 25.0-25.2\% SL). Cathorops manglarensis differs from $C$. multiradiatus in possessing a longer maxillary barbel (28.4-38.2 vs. 22.9-27.7\% SL) (fig. 3) and pectoral fin spine (18.5-22.5 vs. 16.9-18.7\% SL), and longer and wider accessory tooth plates with large and numerous molariform teeth (fig. 5) (vs. shorter and narrow accessory tooth plates with small and few molariform teeth) (fig. 9). Cathorops manglarensis differs from C. tuyra in possessing a longer internal mental barbel (12.517.9 vs. 8.20-12.4\% SL) and pectoral fin spine (18.5-22.5 vs. 16.9-18.7\% SL), shorter nuchal plate (5.0-6.8 vs. $6.8-7.5 \%$ SL), longer anal fin base (21.0-24.5 vs. 13.9-18.3\% SL), deeper caudal peduncle (7.8-8.9 vs. $5.8-7.8 \% \mathrm{SL}$ ), and accessory tooth plates and dentary with moderately large molariform teeth ( $v s$. accessory tooth plates and dentary with very large molariform teeth).

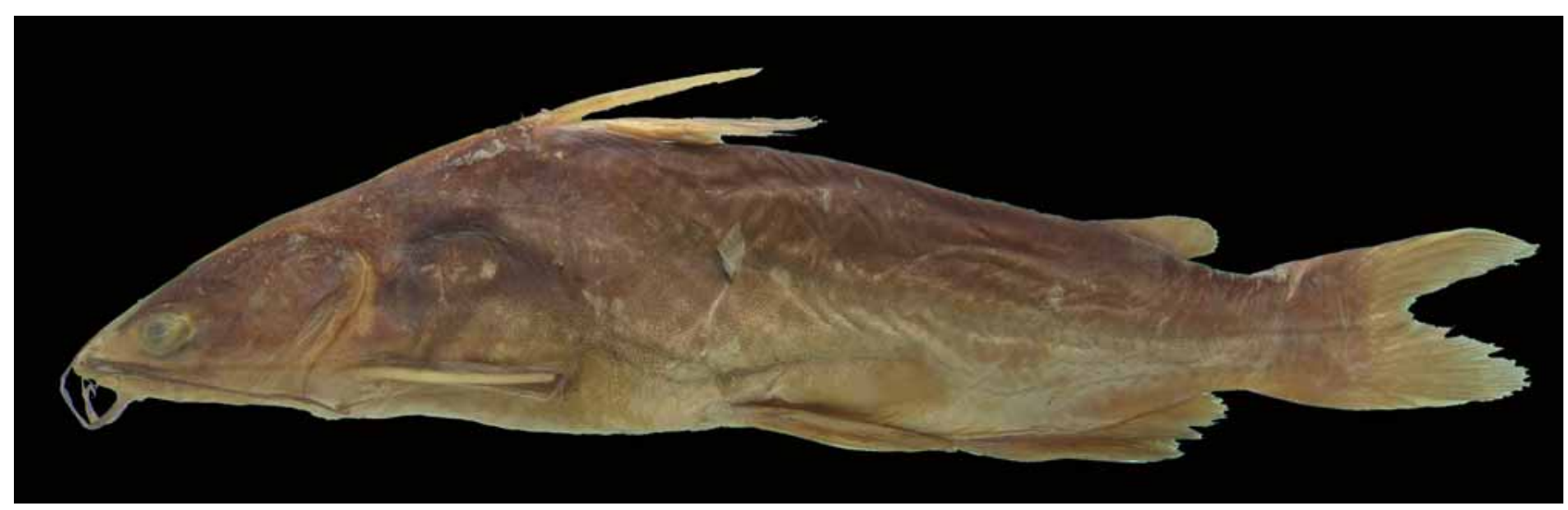

FIGURE 1. Cathorops manglarensis, holotype, USNM 286392, female, $164.0 \mathrm{~mm}$ SL. Body in lateral view.

Description. (Table 1 and 2). Head moderately long and depressed, profile slightly convex at level of frontals and supraoccipital. Body wider than deeper on pectoral girdle area. Cephalic shield of moderate length granulated and visible under skin, broad around lateral ethmoid, frontal, supracleithrum and epioccipital areas. Osseous bridge formed by lateral ethmoid and frontal slender and visible under skin. Medial groove of neurocranium formed by frontals and supraoccipital very distinct, deep and large; progressively narrower posteriorly. Supraoccipital process funnel shaped short, its posterior part considerably narrower than its base, profile moderately convex. Nuchal plate half moon shaped, short and narrow. Snout round in transverse section. Anterior nostrils close to each other and posterior nostrils moderately distant among themselves. Eye lateral of moderate size. Interorbital distance moderate and distance between nostrils and orbit small. Long barbels, maxillary pair reaching half length of pectoral fin spine, external mental pair surpassing margin of gill membrane, internal pair reaching margin of gill membrane.

Mouth of moderate size, lower jaw moderately arched. Lips moderately thick, lower thicker than upper. Vomerine tooth plates absent. One pair of oval shaped accessory tooth plates large and close to one another, sometimes in contact in anterior portion. Accessory tooth plates with large molariform teeth. Premaxillary moderately long and wide. Dentary with well pronounced posterior projection, with sharp teeth on anterior portion, molariform teeth on posterior portion and some conical teeth on intermediary area. Thirteen to sixteen (15) acicular gill rakers on first arch, 5 (5) on upper limb, 8-11 (10) on lower limb. Sixteen to eighteen (17) spike-shaped gill rakers on second arch, 5-6 (5) on upper limb, 11-12 (12) on lower limb. 


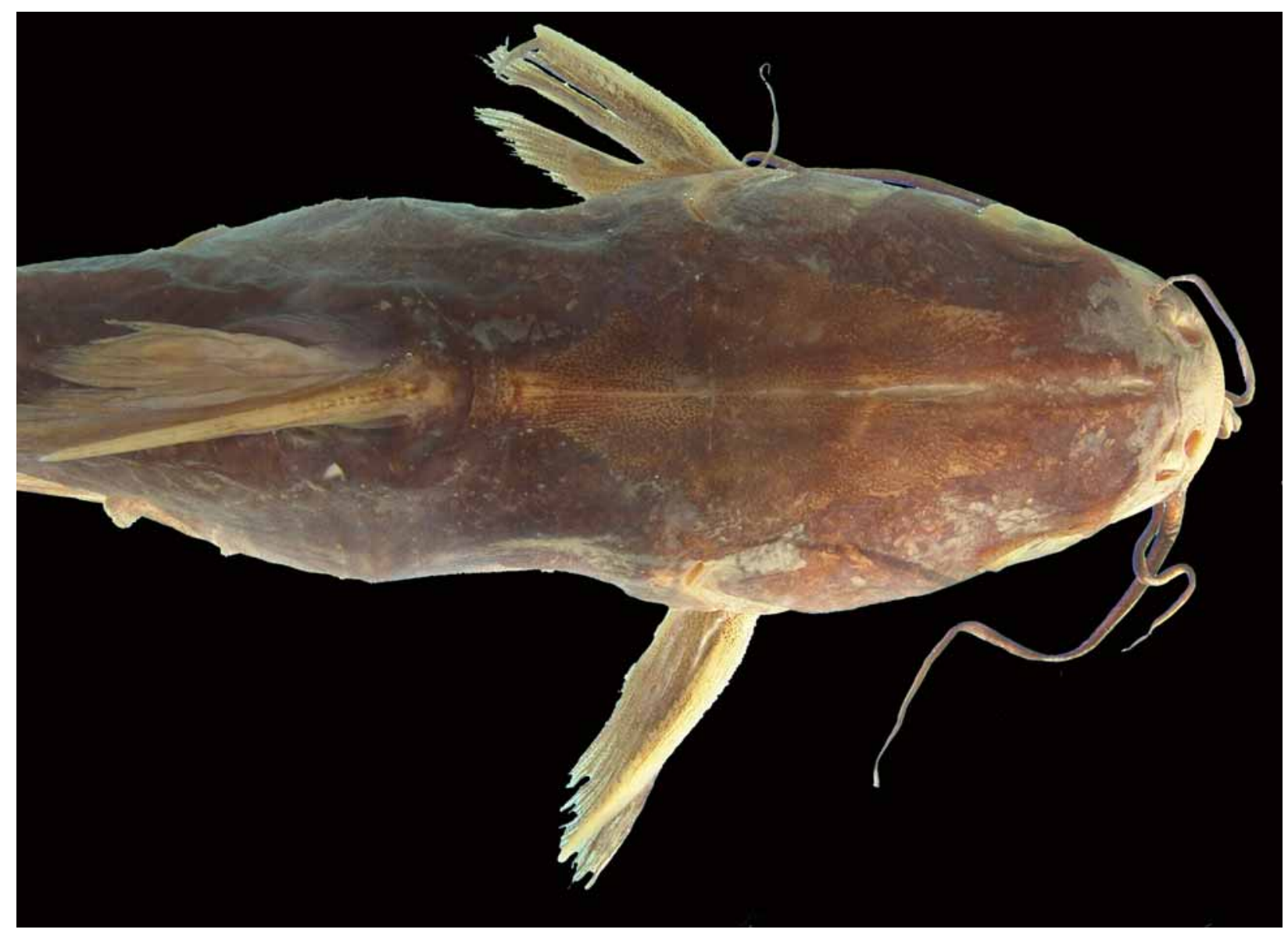

FIGURE 2. Cathorops manglarensis, holotype, USNM 286392, female, 164.0 mm SL. Head in dorsal view.

TABLE 1. Counts of Cathorops manglarensis and Cathorops multiradiatus.

\begin{tabular}{lllll}
\hline Character & \multicolumn{2}{l}{ C. manglarensis $(\mathrm{n}=8)$} & \multicolumn{2}{l}{$\begin{array}{l}\text { C. multiradiatus }(\mathrm{n}=5) \\
\text { Neotype }\end{array}$} \\
\hline Number of rays & 11 & 10 & 10 & $10-11$ \\
Pectoral fin & 7 & 7 & 7 & 7 \\
Dorsal fin & 6 & 6 & 6 & 6 \\
Pelvic fin & 27 & $24-27$ & 27 & $25-27$ \\
Anal fin & & & & \\
Number of gill rakers & $5+10$ & $5+8-11$ & $6+13$ & $6+10-13$ \\
First arch & $5+12$ & $5-6+11-12$ & $5+12$ & $4-5+10-13$ \\
Second arch & & &
\end{tabular}

Ten (11) soft pectoral fin rays. Pectoral fin spine long and thick; anterior margin granulated on proximal two-thirds, distal third serrated; posterior margin straight on proximal fourth, distal three quarters with short serrations. Seven (7) soft dorsal fin rays. Dorsal fin spine short and thick, shorter than pectoral fin spine; anterior margin granulated on proximal two-thirds, distal third serrated; posterior margin serrated over almost its entire length. Six (6) pelvic fin rays, relatively high and length of base long. Adipose fin small, its base less than half as long as anal fin base. Twenty-four to twenty-seven (27) anal fin rays, deep and length of base long. Upper and lower lobes of caudal fin of moderate length, upper longer than lower. Caudal peduncle high. Lateral line reaching base of caudal-fin upper lobe. 
TABLE 2. Measurements of Cathorops manglarensis. The measurements are expressed as percentages of standard length.

\begin{tabular}{|c|c|c|c|c|c|c|c|}
\hline & \multirow[t]{2}{*}{ Holotype } & \multicolumn{3}{|c|}{ Males } & \multicolumn{3}{|c|}{ Females } \\
\hline & & $\mathrm{n}$ & Mean & Range & $\mathrm{n}$ & Mean & Range \\
\hline Standard length (mm) & 164.0 & 3 & & $107.0-195.0$ & 4 & & $89.0-195.0$ \\
\hline Head length & 24.5 & 3 & 27.5 & $24.6-29.1$ & 4 & 25.2 & $24.5-26.3$ \\
\hline Snout length & 6.4 & 3 & 7.2 & $6.6-8.0$ & 4 & 6.6 & $6.2-7.0$ \\
\hline Distance between anterior nostrils & 4.2 & 3 & 4.4 & $3.9-4.8$ & 4 & 4.0 & $3.6-4.3$ \\
\hline Distance between posterior nostrils & 5.9 & 3 & 6.4 & $5.8-7.1$ & 4 & 6.0 & $5.2-6.7$ \\
\hline Anterior nostril to orbit length & 6.5 & 3 & 7.1 & $7.0-7.2$ & 4 & 6.4 & $5.7-6.8$ \\
\hline Posterior nostril to orbit length & 4.5 & 3 & 4.9 & $4.7-5.1$ & 4 & 4.4 & $3.7-4.7$ \\
\hline Orbital diameter & 4.3 & 3 & 4.1 & $3.7-4.5$ & 4 & 4.3 & $3.9-4.8$ \\
\hline Interorbital distance & 13.4 & 3 & 13.7 & $12.1-14.8$ & 4 & 13.1 & $12.0-13.9$ \\
\hline Maxillary barbel length & 28.9 & 3 & 31.1 & $28.4-35.3$ & 4 & 35.5 & $33.4-38.2$ \\
\hline External mental barbel length & 19.9 & 3 & 21.2 & $19.7-22.1$ & 4 & 23.1 & $21.6-24.4$ \\
\hline Internal mental barbel length & 17.9 & 3 & 13.9 & $12.5-14.7$ & 4 & 15.7 & $14.7-17.0$ \\
\hline Snout to maxillary barbel length & 2.1 & 3 & 2.5 & $1.6-3.6$ & 4 & 2.6 & $2.3-2.7$ \\
\hline Snout to external mental barbel length & 3.3 & 3 & 3.9 & 3.7-3.9 & 4 & 3.9 & $3.2-4.4$ \\
\hline Snout to internal mental barbel length & 2.6 & 3 & 3.1 & $2.7-3.3$ & 4 & 3.2 & 2.7-3.9 \\
\hline Mouth width & 9.2 & 3 & 9.9 & $8.8-10.5$ & 4 & 9.1 & $8.7-9.3$ \\
\hline Lower-jaw length & 1.7 & 3 & 2.2 & $1.9-2.7$ & 4 & 1.4 & $1.1-1.7$ \\
\hline Premaxillary length & 1.3 & 3 & 1.4 & $1.3-1.5$ & 4 & 1.4 & $1.3-1.6$ \\
\hline Premaxillarys width & 6.4 & 3 & 7.1 & $6.8-7.4$ & 4 & 6.4 & $6.2-6.9$ \\
\hline Distance between accessory tooth plates & 3.9 & 3 & 5.5 & $4.0-6.5$ & 4 & 4.1 & $3.6-4.6$ \\
\hline Length of accessory tooth plates & 4.4 & 3 & 3.9 & $3.4-4.5$ & 4 & 3.9 & $2.4-4.8$ \\
\hline Width of accessory tooth plates & 2.2 & 3 & 1.7 & $1.5-1.9$ & 4 & 1.9 & $1.0-2.5$ \\
\hline Width of cephalic shield at lateral ethmoid area & 12.4 & 3 & 13.3 & $11.9-14.2$ & 4 & 12.5 & $11.8-12.8$ \\
\hline Width of cephalic shield at frontals area & 7.3 & 3 & 7.8 & 7.7-7.9 & 4 & 7.1 & $6.7-7.5$ \\
\hline Width of cephalic shield at epioccipital area & 12.0 & 3 & 12.2 & $12.0-12.7$ & 4 & 12.7 & $11.9-13.2$ \\
\hline Width of cephalic shield at supracleithrum area & 18.0 & 3 & 18.3 & $17.7-19.0$ & 4 & 18.7 & $18.1-19.4$ \\
\hline Lateral ethmoid to supracleithrum distance & 21.3 & 3 & 23.6 & $20.3-25.6$ & 4 & 21.9 & $20.2-23.1$ \\
\hline Snout to post. margin of medial groove length & 20.7 & 3 & 24.0 & $19.5-26.6$ & 4 & 21.4 & $19.0-23.7$ \\
\hline Supraoccipital process length & 10.5 & 3 & 9.4 & $8.1-10.7$ & 4 & 10.7 & $8.7-12.6$ \\
\hline Supraoccipital process width & 2.8 & 3 & 2.8 & 2.7-3.0 & 4 & 3.0 & $2.8-3.3$ \\
\hline Nuchal-plates length & 6.8 & 3 & 6.1 & $6.1-6.3$ & 4 & 5.9 & $5.0-6.7$ \\
\hline Nuchal-plate width & 7.1 & 3 & 6.6 & $6.4-6.8$ & 4 & 6.6 & $6.4-6.7$ \\
\hline Body height & 17.4 & 3 & 17.2 & $15.6-18.5$ & 4 & 18.6 & $18.2-19.0$ \\
\hline Body width & 21.3 & 3 & 21.3 & $20.8-21.9$ & 4 & 21.1 & $20.7-21.8$ \\
\hline Snout to pectoral fin length & 18.4 & 3 & 23.3 & 20.3-26.6 & 4 & 22.3 & $20.9-23.8$ \\
\hline Snout to dorsal fin length & 33.4 & 3 & 35.9 & $32.3-38.3$ & 4 & 33.5 & $31.7-34.3$ \\
\hline Snout to pelvic fin length & 48.5 & 3 & 47.9 & $46.0-49.6$ & 4 & 49.4 & 48.3-50.9 \\
\hline Snout to adipose fin length & 76.2 & 3 & 75.6 & $73.7-78.4$ & 4 & 74.8 & $72.4-76.1$ \\
\hline Snout to anal fin length & 62.4 & 3 & 63.6 & $61.7-65.1$ & 4 & 63.7 & $61.8-64.6$ \\
\hline
\end{tabular}


TABLE 2. (continued)

\begin{tabular}{llllllll}
\hline & \multicolumn{3}{c}{ Males } & \multicolumn{3}{c}{ Females } \\
& Holotype & $\mathrm{n}$ & Mean & Range & $\mathrm{n}$ & Mean & Range \\
\hline Caudal-peduncle height & 8.5 & 3 & 8.3 & $7.8-8.7$ & 4 & 8.7 & $8.2-8.9$ \\
Pectoral fin spine length & 18.5 & 3 & 19.1 & $18.6-19.5$ & 4 & 20.5 & $19.6-22.5$ \\
Dorsal fin spine length & 17.9 & 3 & 18.2 & $16.9-19.2$ & 3 & 18.1 & $18.0-18.2$ \\
Pelvic fin base length & 3.8 & 3 & 4.0 & $3.6-4.2$ & 4 & 4.2 & $3.7-4.6$ \\
Pelvic fin height & 15.9 & 3 & 13.1 & $12.1-14.3$ & 4 & 15.3 & $12.8-17.2$ \\
Adipose fin base length & 7.4 & 3 & 8.7 & $7.9-9.6$ & 4 & 8.5 & $7.5-9.6$ \\
Adipose fin height & 3.4 & 3 & 3.7 & $3.6-3.9$ & 4 & 4.1 & $3.6-4.5$ \\
Anal fin base length & 22.1 & 3 & 22.3 & $21.0-24.3$ & 4 & 22.7 & $21.3-24.4$ \\
Anal fin height & 14.0 & 3 & 13.2 & $12.2-14.6$ & 4 & 13.9 & $12.9-14.6$ \\
Caudal fin upper lobe length & 30.3 & 3 & 31.1 & $30.0-32.7$ & 4 & 31.7 & $30.8-33.3$ \\
Caudal fin lower lobe length & 30.1 & 3 & 27.5 & $26.2-28.5$ & 4 & 30.0 & $28.5-31.0$ \\
\hline
\end{tabular}

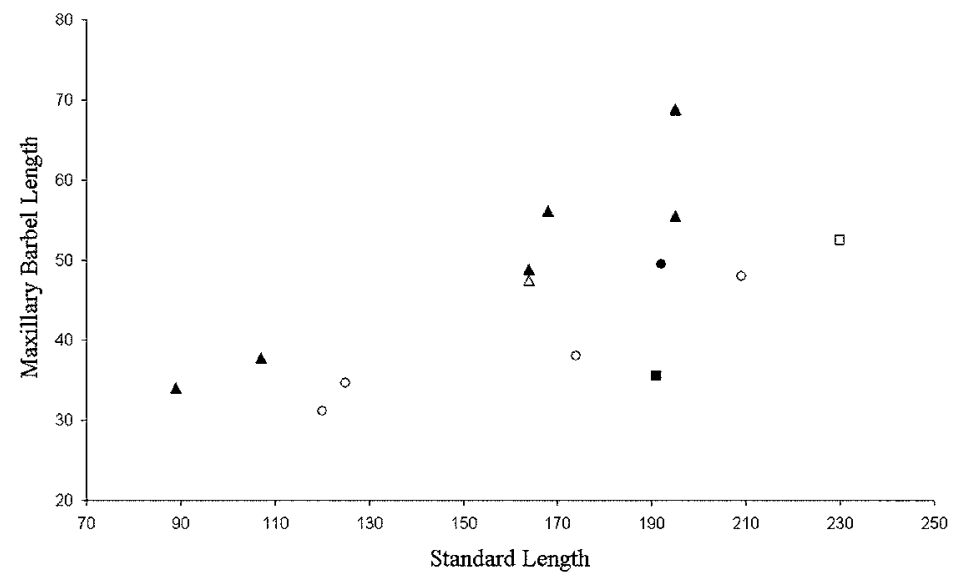

FIGURE 3. Plot of Standard Length against Maxillary Barbel Length, in millimeters, for Cathorops manglarensis (holotype in open triangle; paratypes in filled triangle), Cathorops multiradiatus (neotype in filled circle; other specimens in open circle), Tachysurus emmelane (holotype in open square), and Tachysurus equatorialis (holotype in filled square).

Coloration in alcohol. Head dark brown on dorsal and lateral portions, ventrally whitish. Body with same dark brown color on dorsal portion, progressively lighter towards lateral line and whitish under lateral line, with few brown spots. Barbels dark brown. All fins dark beige overall.

Etymology. The specific epithet "manglarensis" makes reference to type-locality and life habit of the species, common in mangrove regions and estuaries from the Colombian Pacific.

Sexual dimorphism. Sexual dimorphism was observed in 5 females (89.0-195.0 mm SL) and 3 males (107.0-195.0 mm SL) with respect to the following morphological features (Table 2).

Males with larger and wider head than females, as evidenced by longer head, longer snout, greater distance between anterior and posterior nostril and orbit, greater distance between lateral horn of lateral ethmoid and external branch of supracleithrum, and wider cephalic shield on lateral ethmoid and frontal areas. Anterior portion of body relatively longer in males than in females, as evidenced by greater distance from tip of snout to pectoral and dorsal fins origin and greater distance from tip of snout to posterior margin of medial groove of neurocranium. Females have larger distance from tip of snout to pelvic fin origin and deeper body than males. 


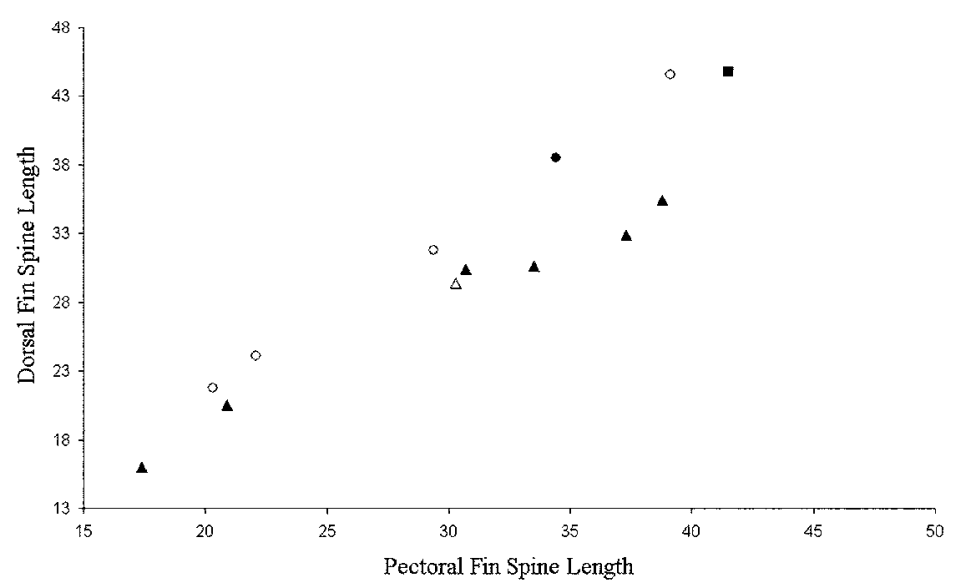

FIGURE 4. Plot of Pectoral Fin Spine Length against Dorsal Fin Spine Length, in millimeters, for Cathorops manglarensis (holotype in open triangle; paratypes in filled triangle), Cathorops multiradiatus (neotype in filled circle; other specimens in open circle), and Tachysurus emmelane (holotype in filled square).

Accessory tooth plates remarkably wider in females and consequently more distant from one another in males (fig. 5). Males with smaller and fewer molariform teeth on accessory tooth plates than females (fig. 5). Accessory tooth plates totally or partially covered by epithelial tissue in males. Dentary in females with a longer posterior projection and with larger and more numerous molariform teeth on its posterior portion than males (fig. 5). Lower jaw longer in males than females and premaxillary and mouth wider in males.

Pelvic fin higher and longer in base in females than in males. Females present a larger orbital diameter, wider supraoccipital process, longer pectoral fin spine, longer lower lobe of caudal fin and relatively longer barbels than males.
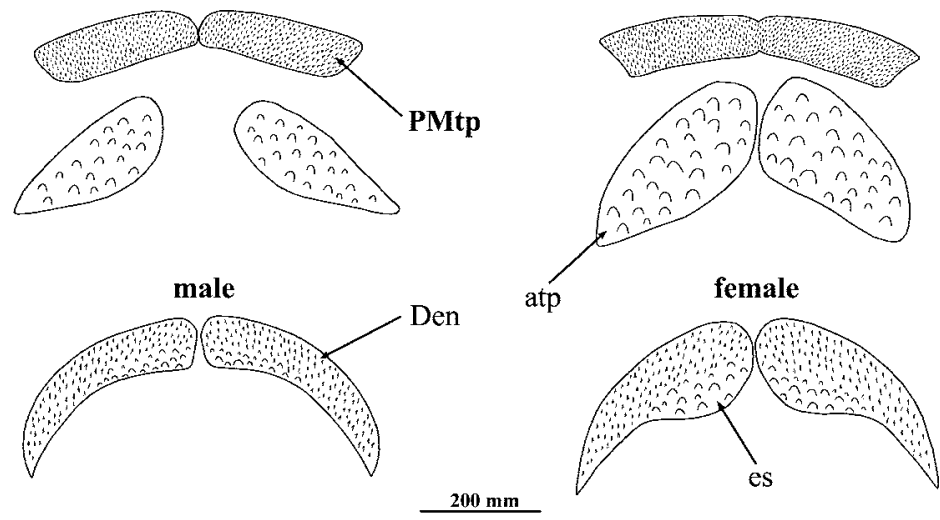

FIGURE 5. Tooth plate of Cathorops manglarensis. Abbreviations: atp - accessory tooth plate; Den - Dentary; pe - posteri or expansion; PMtp - premaxillary tooth plate.

Distribution. The species is described based on specimens collected in localities close to Tumaco, on the Pacific coast of Colombia (fig. 6). Apparently it is common in mangrove areas and lower portions of coastal rivers.

Material Examined. Holotype. USNM 286392 (female, $164.0 \mathrm{~mm} \mathrm{SL}$ ) Colombia, off Cape Manglares,

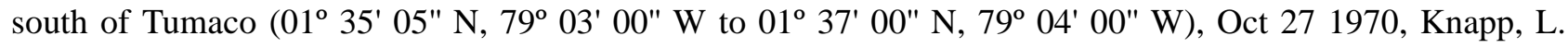
Paratypes. USNM 388316 (8, 164.0-195 mm SL) collected with holotype; USNM 286388 (3, 195-195 mm

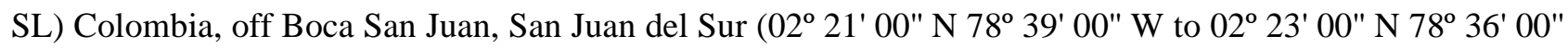


W), Oct. 20 1970, Knapp, L.; USNM 286389 (2, 89.0-107.0 mm SL) Colombia, off Boca San Juan, north of Tumaco $\left(02^{\circ} 20^{\prime} \mathrm{N} 78^{\circ} 40^{\prime} \mathrm{W}\right.$ to $\left.02^{\circ} 23^{\prime} \mathrm{N} 78^{\circ} 41^{\prime} \mathrm{W}\right)$, Oct 28 1970, Knapp, L..

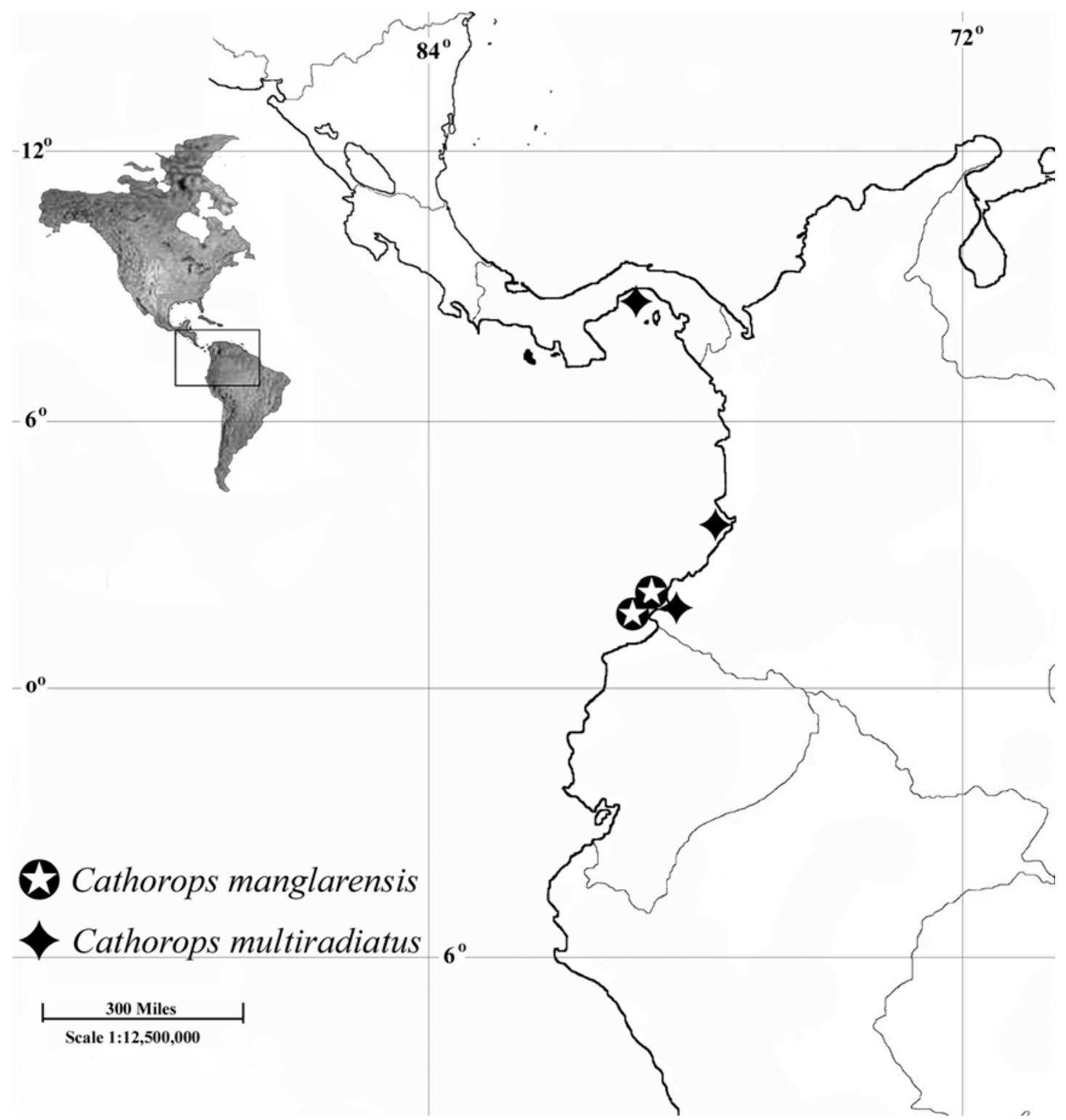

FIGURE 6. Pacific Central and South America, showing the geographic distribution of Cathorops manglarensis and Cathorops multiradiatus.

\section{Cathorops multiradiatus}

(fig. 7 and 8)

Bagrus arioides Kner, 1863: 227, fig. 15 [Type locality: río Bayano, Panama. Holotype: ZSM destroyed. Preoccupied by Bagrus arioides Valenciennes, 1840, objectively invalid].

Arius multiradiatus Günther, 1864: 173 [New name for Bagrus arioides Kner, 1863. No type designated].- Regan, 1906: 126 and 128 [Panama; diagnosis in key; synonymy; brief redescription].- Meek \& Hildebrand, 1923: 122 and 123 [Panama: Chame Point, Balboa, Panama City Market; diagnosis in key; redescription].- Hildebrand, 1946: 127, fig. 28 [Ecuador: Gulf of Guayaquil off Puerto Pizarro, Panama: Panama Bay; synonymy; redescription; distribution].

Tachisurus multiradiatus.- Eigenmann \& Eigenmann, 1888: 146 [only name].- Eigenmann \& Eigenmann, 1890: 50 and 92 [diagnosis in key; synonymy; distribution].

Tachysurus multiradiatus.- Jordan \& Evermann, 1896: 121 and 132 [diagnosis in key; synonymy; brief redescription]. 
Tachysurus emmelane Gilbert, 1898: 2785 [Type locality: Panama. Holotype: SU 5818].- Gilbert \& Starks, 1904: 31 , pl. 6, figs. 11 and 11a [Panama: Panama Bay; redescription].

Tachysurus equatorialis Starks, 1906: 766 [Type locality: Guayaquil, Ecuador. Holotype: USNM 53470].- Evermann \& Radcliffe, 1917 [Ecuador; redescription].

Cathorops multiradiatus.- Allen \& Robertson, 1994: 69 [new combination].- Kailola \& Bussing, 1995 : 862 and 881 [diagnosis in key; synonymy; redescription].- Chirichigno \& Vélez, 1998: 160 [Peru; diagnosis in key].- Eschmeyer et al., 1998 [synonymy, distribution].- Marceniuk \& Ferraris, 2003: 449 [synonymy, distribution].- Ferraris, 2007: 40 [synonymy, distribution].

Diagnosis. Cathorops multiradiatus can be distinguished from all congeners by the following combination of characters: 16-19 gill rakers on first arch; 15-18 gill rakers on second arch; 25-27 anal fin rays; posterior margin of pectoral fin spine with long and conspicuous serrations.

Additional characters help distinguish this species from each of its congeners from the Pacific coast of Central and South America. Cathorops multiradiatus is distinguished from C. dasycephalus in possessing vomerine tooth plates absent ( $v s$. vomerine tooth plates present) and osseous bridge formed by lateral ethmoid and frontal without granulation (vs. granulated osseous bridge along its length). Cathorops multiradiatus differs from $C$. fuerthii in having medial groove of neurocranium deep and large, with lateral margins regular and progressively narrower posteriorly ( $v s$. median groove narrow and shallow, with irregular margins along its length), shorter distance between posterior nostrils (5.1-5.8 vs. 5.8-7.3\% SL), larger orbital diameter (4.1-5.2 vs. 3.7-4.1\% SL), accessory tooth plates shorter (2.1-2.8 vs. 3.9-4.9\% SL) and narrower (0.7-1.2 vs. 1.6$2.2 \% \mathrm{SL}$ ), and shorter pectoral fin spine (16.9-18.7 vs. 19.5-21.0\% SL). Cathorops multiradiatus differs from C. hypophthalmus in possessing a shorter distance between anterior nostrils (3.7-4.5 vs. 6.9-7.1\% SL) and between posterior nostrils (5.1-5.8 vs. 8.2-8.5\% SL), larger orbital diameter (4.1-5.2 vs. 3.0-3.5\% SL), shorter external mental barbel (18.4-24.6 vs. 34.5-38.1\% SL), shorter internal mental barbel (8.6-16.7 vs. 26.1-31.2\% SL), and shorter dorsal fin spine (18.2-21.3 vs. 25.0-25.2\% SL). Cathorops multiradiatus differs from C. manglarensis in possessing a shorter maxillary barbel (22.9-27.7 vs. 28.4-38.2\% SL) (fig. 3), shorter pectoral fin spine (16.9-18.7 vs. 18.5-22.5\% SL), dorsal fin spine longer than pectoral fin spine (vs. dorsal fin spine shorter than pectoral fin spine) (fig. 4), and shorter and narrow accessory tooth plates, with small and few molariform teeth (fig. 9) (vs. longer and wider accessory tooth plates, with large and numerous molariform teeth) (fig. 5). Cathorops multiradiatus differs from C. tuyra in possessing a shorter distance from tip of snout to dorsal fin origin (31.2-34.8 vs. 34.5-39.8\% SL), shorter supraoccipital process (9.8-11.5 vs. 11.3$13.7 \% \mathrm{SL}$ ), and accessory tooth plates and dentary with relatively small molariform teeth ( $v s$. accessory tooth plates and dentary with very large molariform teeth).

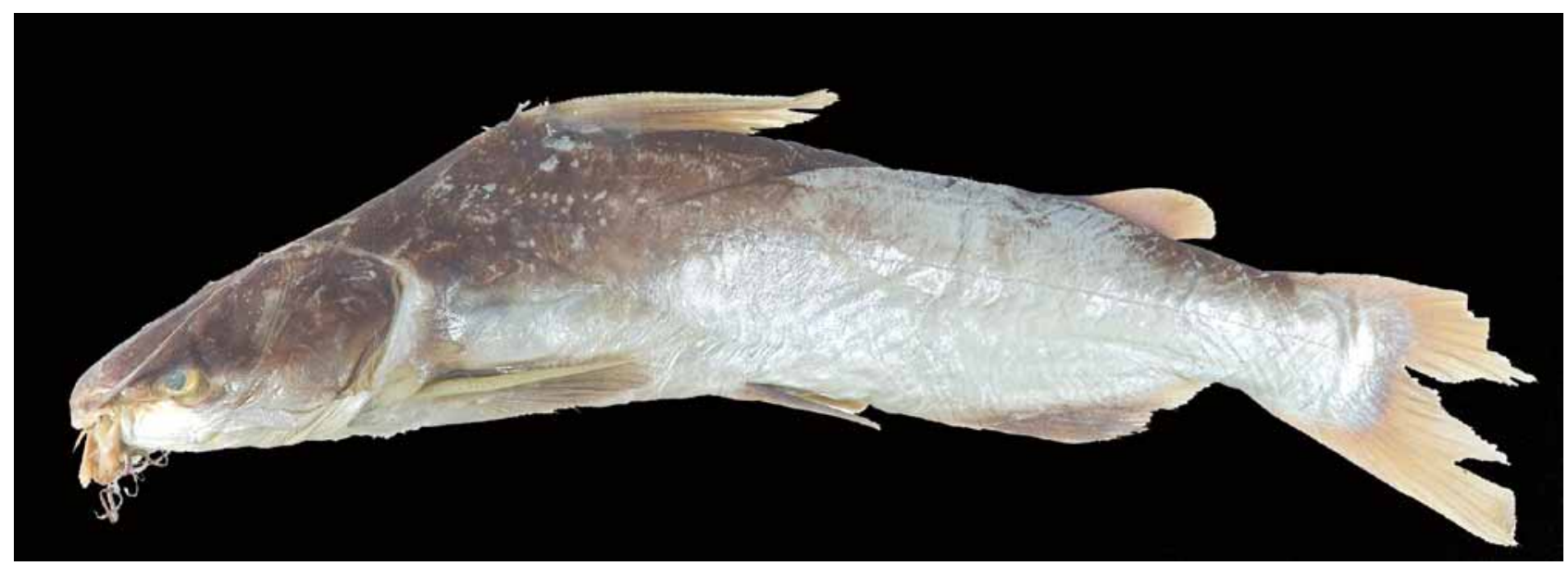

FIGURE 7. Cathorops multiradiatus, neotype, USNM 79408, male, 192.0 mm SL. Body in lateral view. 
TABLE 3. Measurements of Cathorops multiradiatus. The measurements are expressed as percentages of standard length.

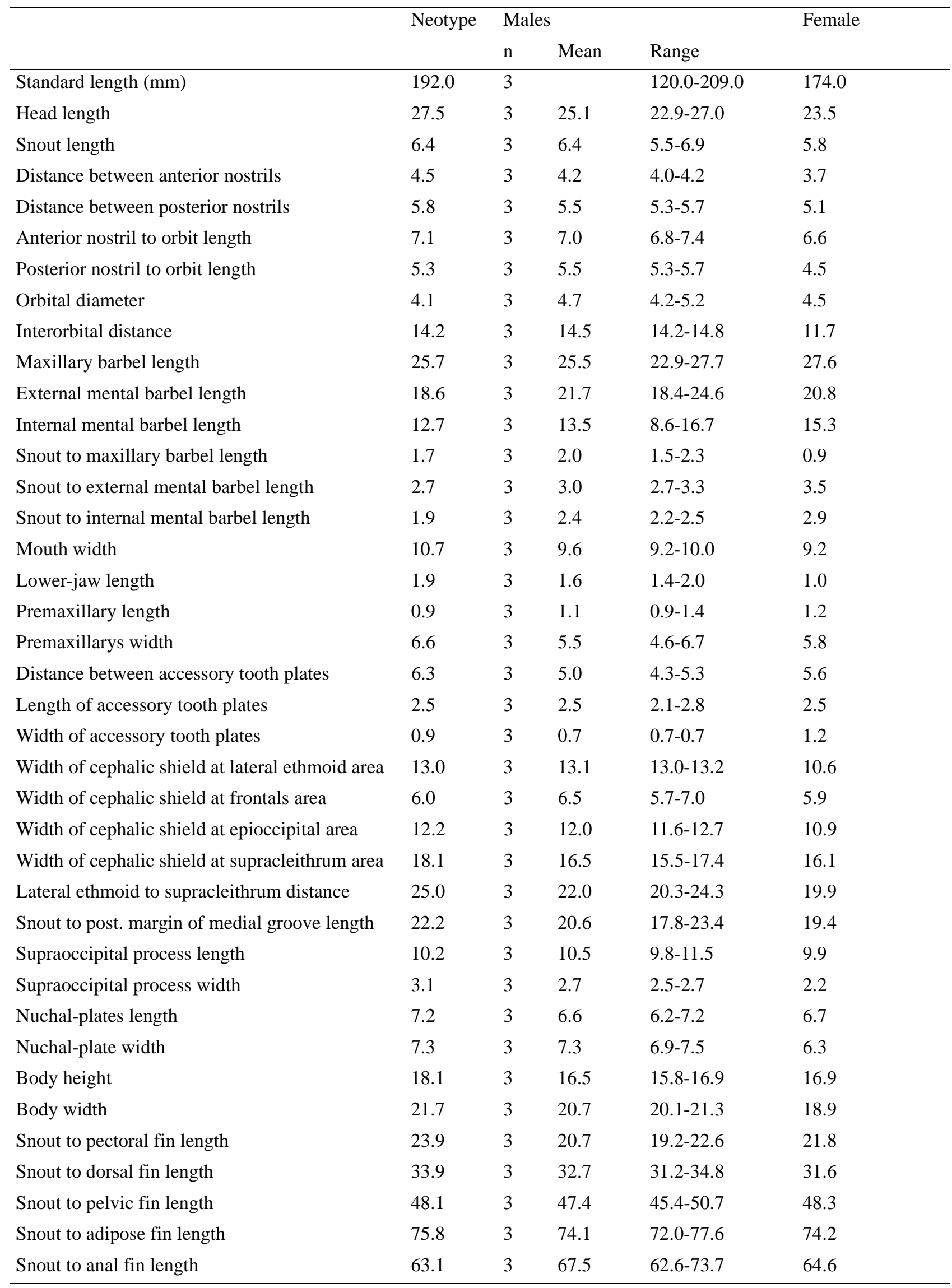

to be continued. 
TABLE 3. (continued)

\begin{tabular}{llllll}
\hline & Neotype & \multicolumn{2}{l}{ Males } & & Female \\
& & $\mathrm{n}$ & Mean & Range & \\
\hline Caudal-peduncle height & 8.6 & 3 & 9.7 & $9.1-10.1$ & 7.2 \\
Pectoral fin spine length & 17.9 & 3 & 17.8 & $16.9-18.7$ & 16.9 \\
Dorsal fin spine length & 20.1 & 3 & 19.6 & $18.2-21.3$ & 18.3 \\
Pelvic fin base length & 3.5 & 3 & 4.2 & $4.1-4.4$ & 4.3 \\
Pelvic fin height & 12.1 & 3 & 13.1 & $12.9-13.7$ & 13.6 \\
Adipose fin base length & 8.8 & 3 & 7.5 & $5.8-9.0$ & 7.6 \\
Adipose fin height & 4.1 & 3 & 4.1 & $3.7-4.3$ & 3.5 \\
Anal fin base length & 20.0 & 2 & 22.3 & $21.5-23.2$ & 21.2 \\
Anal fin height & 9.4 & 2 & 13.6 & $13.5-13.7$ & 12.5 \\
Caudal fin upper lobe length & - & 2 & 31.6 & $31.4-31.8$ & 31.7 \\
Caudal fin lower lobe length & - & 2 & 29.5 & $29.8-30.0$ & 28.0 \\
\hline
\end{tabular}

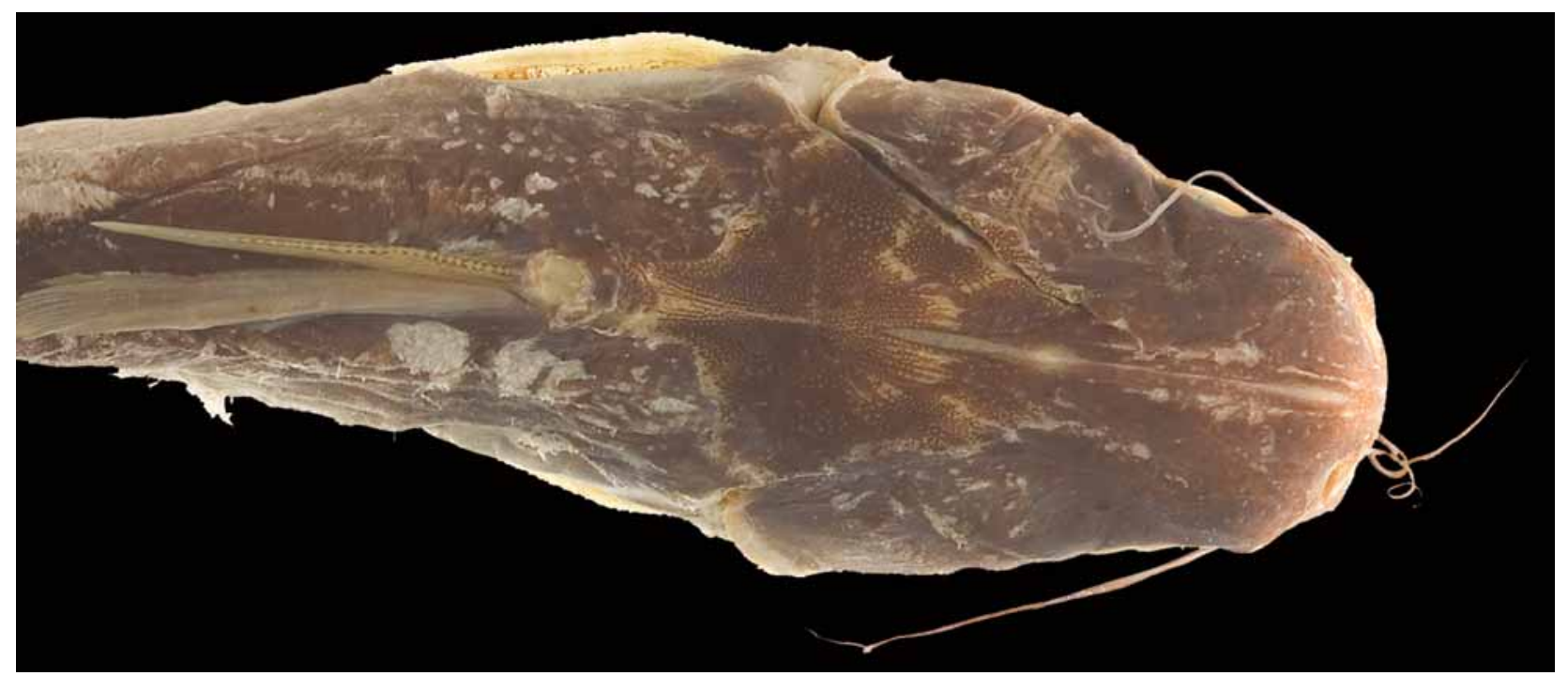

FIGURE 8. Cathorops multiradiatus, neotype, USNM 79408, male, $192.0 \mathrm{~mm}$ SL. Head in dorsal view.

Description. (Table 1 and 3). Head moderately long and depressed, profile slightly convex at level of frontals and supraoccipital. Body wider than deeper on pectoral girdle area. Cephalic shield moderately granulated and visible under skin, moderately long and broad on lateral ethmoid and epioccipital area and narrow on frontal and supracleithrum areas. Osseous bridge formed by lateral ethmoid and frontals slender and visible under skin. Medial groove of neurocranium formed by frontals and supraoccipital very distinct, deep and large, progressively narrower posteriorly. Supraoccipital process of moderate length and funnel shaped, its posterior part considerably narrower than its base and profile moderately convex. Nuchal plate half moon shaped, long and wide. Snout round in transverse section. Anterior and posterior nostrils closer among themselves. Eyes lateral and relatively large. Interorbital distance and distance between nostrils and orbit large. Short maxillary barbel, reaching base of pectoral fin spine and moderately long mental barbels, external mental pair reaching margin of gill membrane, internal pair not reaching margin of gill membrane.

Mouth of moderate size, lower jaw moderately arched. Lips moderately thick, lower thinner than upper. Vomerine tooth plates absent. One pair of elongated and narrow oval shaped accessory tooth plates, quite small and distant from each other. Accessory tooth plates with small molariform teeth. Premaxillary moderately long and wide. Dentary with posterior projection poorly development or absent, with many sharp teeth 
on anterior portion and few small molariform teeth on posterior portion. Sixteen to nineteen (19) acicular gill rakers on first arch, 6 (6) on upper limb, 10-13 (13) on lower limb. Fifteen to eighteen (17) spike shaped gill rakers on second arch, 4-5 (5) on upper limb, 10-13 (12) on lower limb.

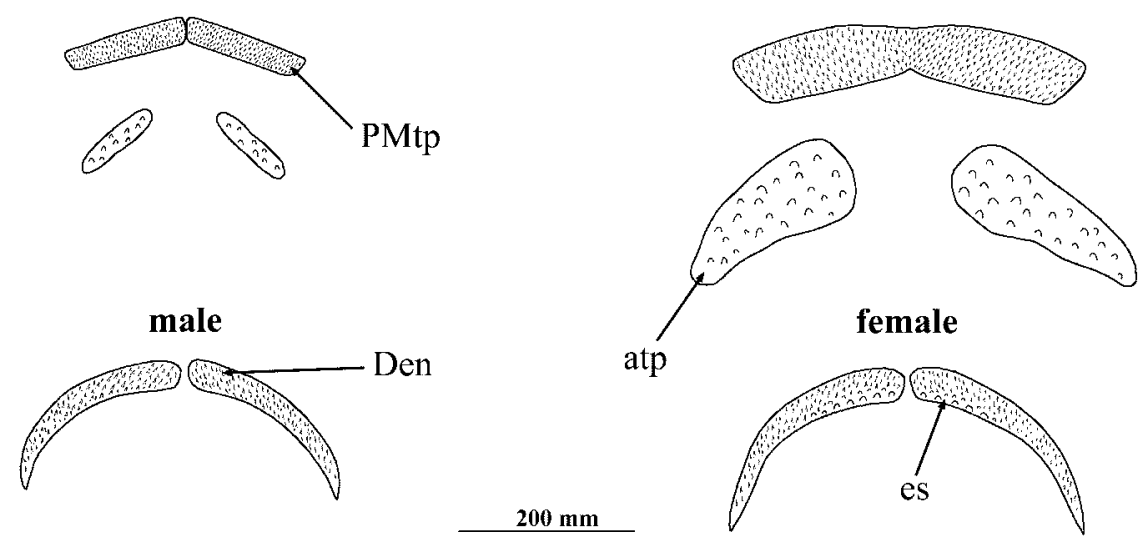

FIGURE 9. Tooth plate of Cathorops multiradiatus. Abbreviations: atp - accessory tooth plate; Den - Dentary; pe - posterior expansion; PMtp - premaxillary tooth plate.

Ten to eleven (10) soft pectoral fin rays. Pectoral fin spine short and thin; anterior margin granulated on two thirds, serrated on distal third; posterior margin straight on basal fourth, distal three quarters with quite long serrations. Seven (7) dorsal fin rays. Dorsal fin spine of moderate length and thin, longer than pectoral fin spine; anterior margin granulated on basal two thirds, distal third serrated; posterior margin serrated almost all its length. Six (6) pelvic fin rays, low and length of base long. Adipose fin small, its base less than half as long as anal fin base. Twenty-five to twenty-seven (27) anal fin rays, low and length of base long. Upper and lower lobes of caudal fin of moderate length, upper longer than lower. Caudal peduncle high. Lateral line reaching base of caudal fin upper lobe.

Coloration in alcohol. Head dark brown on dorsal and lateral portions, ventrally whitish. Body with same dark brown color on dorsal portion, progressively lighter towards lateral line and whitish under lateral line, with few brown spots. Barbels dark brown. All fins dark beige overall.

Sexual dimorphism. Sexual dimorphism was observed in 1 female (174.0 mm SL) and 4 males (120.0$209.0 \mathrm{~mm} \mathrm{SL}$ ) with respect to following morphological features (Table 3).

Males with relatively longer and wider head than females, as expressed by longer head, longer snout, greater distance between nostrils and orbit, greater distance between lateral horn of lateral ethmoid and external branch of supracleithrum, greater distance from tip of snout to posterior margin of medial groove of neurocranium, greater distance from tip of snout to dorsal and anal fins origin, greater interorbital distance, greater distance between nostrils, and wider cephalic shield on lateral ethmoid, frontal and epioccipital areas. Males have wider body than females.

Females with larger accessory tooth plates than males (fig. 9) and males with accessory tooth plates generally covered by epithelial tissue. Dentary in females with a longer posterior expansion and larger and more molariform teeth on posterior portion than males (fig. 9).

Pelvic fin and maxillary barbel longer in females than in males. Males present longer pectoral and dorsal fin spines, relatively longer caudal fin lower lobe, and deeper caudal peduncle than females.

Distribution. The literature indicates that $C$. multiradiatus occurs from Guatemala to Paita, Peru (Hildebrand, 1946; Kailola \& Bussing, 1995). The examined specimens are from Panama and Colombia (fig. 6). Common in shallow coastal areas and mangrove regions.

Remarks. Kner (1863) described Bagrus arioides based on one specimen collected in the River Bayano, in Panama. The name is preoccupied by a species described by Valenciennes (1840) from Bengal, India. Hom- 
onymy was recognized by Günther (1864), who proposed Arius multiradiatus as a replacement for Bagrus arioides Kner, 1863. According to Article 59 (a) of the International Code of Zoological Nomenclature (1999), which deals with cases of primary homonyms, Bagrus arioides Kner, 1863 must be definitely rejected and recognized as an invalid senior synonym of Cathorops multiradiatus (Günther, 1864). The specimen examined by Kner (1863) was destroyed (personal communication of Dirk Neumann) and C. multiradiatus may be recognized by its original description, partially reproduced by Günther (1864), with the number of anal-fin rays was long identified as an exclusive characteristic of the species within the genus (Eigenmann \& Eigenmann, 1890; Jordan \& Evermann, 1896; Regan, 1906; Meek \& Hildebrand, 1923; Hildebrand, 1946; Kailola \& Bussing, 1995). Cathorops manglarensis has a similar number of anal-fin rays, rendering the recognition of $C$. multiradiatus imprecise, if based exclusively on its original description. Given the loss of the holotype, the previously only known type specimen of B. arioides, a neotype is herein designated to insure the stability of the name and to avoid future doubts concerning the identity of the species. The specimen chosen as neotype of C. multiradiatus is a male of $192.0 \mathrm{~mm} \mathrm{SL}$, from the Bay of Panama, belonging to the National Museum of Natural History (USNM 79408).

The nominal species Tachysurus emmelane Gilbert, 1898 and Tachysurus equatorialis Starks, 1906, are recognized as junior synonyms of $C$. multiradiatus. The determination of the specific status of both nominal species is based on their original descriptions. Tachysurus emmelane Gilbert, 1898 was described based on one specimen of $280 \mathrm{~mm}$ TL, colleted in Panama. The original description presents characteristics of the species common to $C$. multiradiatus, which also distinguishes it from C. manglarensis: "posterior mandibular (dentary) teeth stronger than those in front bluntly conic, not, however, granular or flat and pavement like (molariform), as are the posterior mandibular teeth in T. fuerthii, T. melanopus and T. liropus", "palatine (accessory tooth plates) teeth granular (molariform), in small oblanceolate patches, which taper to a point laterally, and are widely separated on medial line, the patches agreeing in size and shape with those in T. liropus", "the maxillary barbels reaching edge of gill membrane in front of pectoral spine, the outer mental barbels extending beyond gill membrane, ..., the inner not to edge of membrane", "gill rakers $6+13$ ", "dorsal spine ... its length to tip of calcified portion $12 / 5$ in head" and "pectoral spine strong, ridged and granulated in front, the hinder edge with very strong serrae; length of spine $13 / 4$ in head". Additionally, the type specimen of T. emmelane was examined by Dave Catania (Department of Ichthyology, California Academy of Sciences), that sent the following data on the type: $6+13$ gill rakers on first gill arch; $6+13$ gill rakers on second gill arch; maxillary barbel $52.4 \mathrm{~mm}(22.8 \%$ SL) (fig. 3); pectoral fin spine $41.5 \mathrm{~mm}$ (17.9\% SL) (fig. 4); dorsal fin spine $44.8 \mathrm{~mm}$ (19.5\% SL and longer than pectoral-fin spine) (fig. 4); pectoral fin spines with long and conspicuous serrations on posterior surface.

Starks (1906) described Tachysurus equatorialis based on only one specimen from Guayaquil, Ecuador. Tachysurus equatorialis differs from C. manglarensis and may be recognized as a synonym of C. multiradiatus based on the following characteristics presented in its original description: "palatine patches (accessory tooth plates) small, elliptical, and widely separated, each bearing about 30 bluntly rounded teeth (molariform); length of each patch two-fifths of length of eye and half as wide as long", "posterior, median, mandibular (dentary) teeth not enlarged as in other species", "maxillary barbel reaching to axillary pore; posmental barbel to base of pectoral spine; and mental barbel to base of branchiostegal membrane" and "gill rakers .... $6+13$ in number". The condition of T. equatorialis as a synonym of $C$. multiradiatus is also based on observations done by Hildebrand (1946). The author redescribed C. multiradiatus based on the examination of three specimens from the Gulf of Guayaquil and on specimens examined by Evermann \& Radcliffe (1917), on which the authors based their redescription of Tachysurus equatorialis (USMN 77596). Hildebrand (1946) compared the cited specimens with specimens from Panama identified as C. multiradiatus and the type-specimen of T. equatorialis (USNM 53470), recognizing that all of them did not differ meaningfully from each other and probably represent the same species. Additionally, the type specimen of T. equatorialis was examined by Carl J. Ferraris (California Academy of Sciences) and Richard P. Vari (Division of Fishes, Smithso- 
nian Institution) and the latter sent the following data on the type: $6+14$ gill rakers on first gill arch; $5+13$ gill rakers on second gill arch; maxillary barbel $35.5 \mathrm{~mm}(18.6 \% \mathrm{SL}$ ) (fig. 3); pectoral fin spine broken; dorsal fin spine broken; pectoral fin spines with long and conspicuous serrations on posterior surface.

Material Examined. Neotype (herein designated): USNM 79408 (male, 192.0 mm SL) Panama, Panama Bay, Balboa, canal zone, May 05 and 06 1911, Meek, S. E. \& Hildebrand, S. F. USNM 388315 (1, 209.0 mm SL) collected with neotype; USNM 292703 (1, $174.0 \mathrm{~mm}$ SL) Colombia, Sandy Beach immediately South of Punta Canchaco in enseada de Juan Chaco, about 1, 1/2 hrs. by motor boat north of Buenaventura ( $03^{\circ} 56^{\prime} 40^{\prime \prime}$ N 77² 21' W), Sep 18 1969, Knapp, L.; USNM 00286400 (3, 120.0-125.0 mm SL) Colombia, off Cape Manglares, south of Tumaco ( $01^{\circ} 39^{\prime} 00^{\prime \prime} \mathrm{N} 79^{\circ} 02^{\prime} 30^{\prime \prime} \mathrm{W}$ to $\left.01^{\circ} 37^{\prime} 30^{\prime \prime} \mathrm{N} 79^{\circ} 02^{\prime} 00^{\prime \prime} \mathrm{W}\right)$, Oct 27 1970, Knapp, L.

\section{Key to the species of Cathorops from the Pacific Coast of Central and South America}

1. 37-40 gill rakers on first and second arches; distance between anterior nostrils $6.92-7.14 \%$ SL; distance between posterior nostrils $8.19-8.51 \%$ SL

Cathorops hypophthalmus

- 13-22 gill rakers on first and second arches; distance between anterior nostrils 3.60-5.98\% SL; distance between posterior nostrils $4.23-7.26 \%$ SL ............................................................................. 2

2. Medial groove of neurocranium very narrow and shallow, with irregular margins all its length.

Cathorops fuerthii

- Medial groove of neurocranium deep and large, with lateral margins regular and progressively narrower

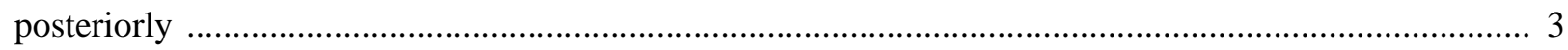

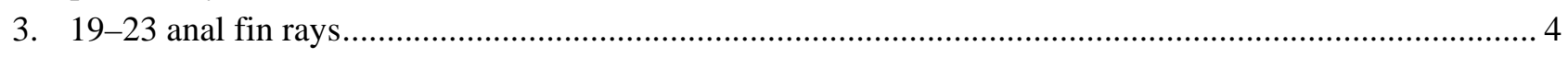

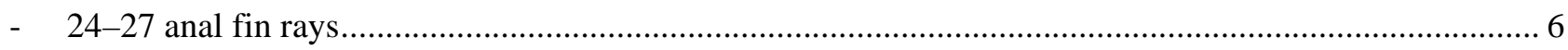

4. Vomerine tooth plates present; osseous bridge formed by lateral ethmoid and frontal granulated in all its length Cathorops dasycephalus

- Vomerine tooth plates absent; osseous bridge formed by lateral ethmoid and frontal without granulation .

5. 19-20 anal fin rays; accessory tooth plates with very large molariform teeth; dentary with a well pronounced posterior projection and very large and numerous molariform teeth on posterior portion

Cathorops tuyra

- 22-23 anal fin rays; accessory tooth plates with molariform teeth of moderate size; dentary with moderately pronounced posterior projection and small and few molariform teeth on posterior portion

Cathorops steindachneri

6. Maxillary barbel 22.9-27.7\% SL; 16-19 gill rakers on first arch; pectoral fin spine 16.9-18.7\% SL; dorsal fin spine longer than pectoral fin spine Cathorops multiradiatus

- Maxillary barbel 28.4-38.2\% SL; 13-16 gill rakers on first arch; pectoral fin spine 18.5-22.5\% SL; dorsal fin spine shorter than pectoral fin spine. Cathorops manglarensis

\section{Acknowledgements}

The author is grateful to Barry Chernoff and Mary Anne Rogers (Field Museum of Natural History) and Susan Jawett, Sandra Raredon and Lisa Palmer (National Museum of Natural History, Smithsonian Institution) for their cooperation in loaning the material used in this study. Thanks to Sandra Raredon and Jeffrey T. Williams for a photograph and counts of the type-specimen of C. multiradiatus, Richard P. Vari, Carl J. Ferraris Jr. and Dave Catania for counts and measurements of the type-specimen of T. equatorialis and T. emmelane and Leandro Melo de Sousa by photograph of the type-specimen of C. manglarensis. Thanks to Naércio Aquino 
Menezes and Flávio César Thadeo de Lima for assistance with revisions of the manuscript. I am grateful to Fundação de Amparo à Pesquisa do Estado de São Paulo (FAPESP) for the support received through Doctoral (Proc.97/11302-3) and Postdoctoral (03/04509-3) scholarships.

\section{References}

Allen, G. R. \& Robertson, D. R. (1994) Fishes of the tropical eastern Pacific. Crawford House Press, Bathurst. Fish Tropical \& Pacific. 332pp.

Betancur-R., R. (2003) Filogenia de los Bagres Marinos (Siluriformes: Ariidae) del Nuevo Mundo. M.Sc.Thesis, Universidad Nacional de Colombia, Bogotá. 121pp.

Betancur-R., R., Acero-P., A. \& Mejia-Ladino, L. M. (2004) Analisis filogenético preliminar de algunos bagres marinos (Siluriformes: Ariidae) neotropicales. Preliminar [Preliminary] phylogenetic analysis of some neotropical marine catfishes (Siluriformes: Ariidae). Memoria de la Fundacion la Salle de Ciencias Naturales, 62, 61-85.

Betancur-R. R., Acero, P. A., Bermingham, E. \& Cooke, R. (in press) Systematics and biogeography of New World sea catfishes (Siluriformes: Ariidae) as inferred from mitochondrial, nuclear, and morphological evidence. Molecular Phylogenetics and Evolution 2007: doi 10.1016/j.ympev.2007.02.022.

Bussing, W. A. \& López, S. M. I. (1994) Demersal and pelagic inshore fishes of the Pacific coast of lower central America. An illustrated guide. Revista de Biologia Tropical, 1-164.

Castro-Aguirre, J. L., Espinosa Pérez, H. S. \& Schmitter-Soto, J. J. (1999) Ictiofauna estuarino-Lagunar y vicaria de México. Colección Textos Politécnicos. Serie Biotechnologías. 711pp.

Chirichigno F. N. \& Vélez, D. J. (1998) Clave para identificar los peces marinos del Peru. Instituto del Mar del Peru, Publicación Especial. 496pp.

Eigenmann, C. H. \& Eigenmann, R. S. (1888) Preliminary notes on South American Nematognathi, I. Proceedings of the California Academy of Sciences, Series 2, 1, 119-172.

Eigenmann, C. H. \& Eigenmann, R. S. (1890) A revision of the South American Nematognathi or cat-fishes. Occasional Papers of the California Academy of Sciences, no. 1, 1-508 + errata and map.

Eschmeyer, W.N., Ferraris, C. J., Jr. Hoang, M. D. \& Long, D. J. (1998) Catalog of fishes. Part I. Species of fishes. Special Publication, California Academy of Sciences, San Francisco, 3 vols. 2905pp.

Evermann, B. W. \& Radcliffe, L. (1917) The fishes of the west coast of Peru and the Titicaca Basin. Bulletin of the United States National Museum, 95, 1-166.

Ferraris, C.J., Jr. (2007) Checklist of catfishes, recent and fossil (Osteichthyes: Siluriformes), and catalogue of siluriform primary types. Zootaxa, 1418, 30-57.

Gilbert, C. H. (1898) In: Jordan, D. S. \& Evermann, B. W. (1898) The fishes of North and Middle America: a descriptive catalogue of the species of fish-like vertebrates found in the waters of North America north of the Isthmus of Panama. Part III. Bulletin of the U. S. National Museum, 47, i-xxiv + 2183a-3136.

Gilbert, C. H. \& Starks, E. C. (1904) The fishes of Panama Bay. Memoirs of the California Academy of Sciences, 4, 1304.

Günther, A. (1864) Catalogue of the Fishes in the British Museum, vol. 5.- Catalogue of the Physostomi, Containing the Families Siluridae, Characinidae, Haplochitonidae, Sternoptychidae, Scopelidae, Stomiatidae in the Collection of the British Museum. Trustees, London, xxii + 455pp.

Hildebrand, S. F. (1946) A descriptive catalog of the shore fishes of Peru. Smithsonian Institution Bulletin United States National Museum, 189, 119-128.

Jordan, D. S. \& Evermann, B. W. (1896) The fishes of North and Middle America: a descriptive catalogue of the species of fish-like vertebrates found in the waters of North America, north of the Isthmus of Panama. Part I. Bulletin of the U. S. National Museum, 47, i-lx +1-1240.

Kailola, P. J. \& Bussing, W. A. (1995) Ariidae. In: Fischer, W., Krupp, F., Schneider, W., Sommer, C., Carpenter, K. E. \& Niem, V. H. (Eds.), Guía FAO para la Identificación para los Fines de la Pesca. Pacifico Centro-oriental. Vol. II. Vertebrados - Parte 1, FAO, Rome. 860-886.

Kner, R. (1863) Eine Uebersicht der ichthyologischen Ausbeute des Herrn Professors Dr. Mor. Wagner in CentralAmerika. Sitzungsber. Koningl. Bayer. Akademie Wissenschaften, Muenchen, 2, 220-230.

Marceniuk, A. P. (1997) Revisão sistemática do gênero Cathorops (Osteichthyes; Siluriformes; Ariidae). MSc degree Thesis, University of São Paulo. 316pp.

Marceniuk, A. P. (2003) Relações Filogenéticas e Revisão dos Gêneros da Família Ariidae (Ostariophysi, Siluriformes). Ph. D. Thesis, Universidade de São Paulo, São Paulo. 383pp.

Marceniuk, A. P. (in prees.) Revalidação de Cathorops arenatus (Valenciennes, 1840) e Cathorops agassizii (Eigenmann \& Eigenmann, 1888) (Siluriformes, Ariidae), das regiões norte e nordeste da América do Sul. Iheringia. 
Marceniuk, A. P. \& Ferraris, C. J., Jr. (2003) Ariidae. In: Reis, R. E., Kullander, S. O. \& Ferraris, C. J., Jr. (Eds.), Check list of the Freshwater Fishes of South and Central America. Edipucrs, Porto Alegre, Brazil, pp. 447-455.

Marceniuk, A. P. \& Menezes, N. A. (2007) Systematics of the family Ariidae (Ostariophysi, Siluriformes), with a redefinition of the genera. Zootaxa, 1416, 1-126.

Meek, S. E. \& Hildebrand, S. F. (1923) The marine fishes of Panama.- Part I. Publication. Zoological Series, Field Museum of Natural History, 15, i-xi + 1-330, pls. 1-24.

Nelson, J. S., Crossman, E. J., Espinosa-Pérez, H., Findley, L. T. \& Gilbert, C. R. (2004) Common and scientific names of fishes from the United States, Canada, and Mexico. Sixth Edition. American Fisheries Society, Special Publ. 29. Bethesda, Maryland. Common and Scientific Names of Fishes U.S.A., Canada and Mexico. Sixth Edition. 386pp.

Regan, C. T. (1906-1908) Pisces. In: Godman, F. D. \& Salvin, O. (Eds.), Biologia Central-Americana, Part 193. London, 1-203, 25 pls.

Starks, E. C. (1906) On a collection of fishes made by P. O. Simons in Ecuador and Peru. Proceedings United States National Museum, 30(1468), 761-800.

Valenciennes, A. (1840) In: Cuvier, G. \& Valenciennes, A. (1840) Histoire Naturelle des Poissons. Tome Quatorzième. Suite du Livre Seizième. Labrö̈des. Livre Dix-septième. Des Malacoptérygiens. Ch. Pitois \& V $\mathrm{v}^{\mathrm{e}}$ Levrault, Paris; Strasbourg, xxii $+2+464+4$ p., pls. 389-420. 